\title{
THE EFFECT OF AFFECTIVE ORGANIZATIONAL COMMITMENT TOWARDS INNOVATION CAPABILITY AND ITS IMPACT TO JOB PERFORMANCE IN FAMILY BUSINESS
}

\author{
Yohana Cahya Wibowo \& Natalia Christiani \\ International Business Management, Universitas Ciputra Surabaya, Surabaya, Indonesia
}

\begin{abstract}
Purpose - the purpose of this research is to find out about the effect of affective organizational commitment towards innovation capability and its impact to job performance in family business. Methodology - the original data was taken through an online questionnaire with 100 respondents who are members of Family Business Community in Universitas Ciputra along with the non-members. The SmartPLS 3.0 Statistics Program was used to test the proposed model. Findings - Result shows that affective organizational commitment significantly affects innovation capability and job performance and innovation capability significantly affects job performance.
\end{abstract}

Keywords: affective organizational commitment, innovation capability, job performance

\section{INTRODUCTION}

Family Business is a common type of businesses in many countries. Few of them are USA, Europe, Indonesia and other Asian Countries. PWC (PricewaterhouseCoopers) stated that family businesses growth in Indonesia has increased from 2016 to 2018 (PWC, 2018). The growth of businesses in Indonesia is $65 \%$. It means that the growth will be aggressive and quick comparing to the global percentage which is only 39\%. According to the survey from PWC (2018), Family Business is in healthy condition with the growth at the highest level since 2007. With that growth data, there are a lot of advantages of running Family Businesses. According to BDO (2019), one of the advantages is powerful commitment.

Horton (1986) in Sreih and Kassar (2017) stated that Family Businesses tend to be more friendly and warm in working environment be-

\footnotetext{
*Corresponding Author.

e-mail: yohanachy@gmail.com
}

cause they have a high sense of commitment among its employees. This research relies on the agency theory because this research focuses also on non-family members. Meaning that the concept of the agency theory is to linked the participation of family members and non-family members in family businesses (Sreih and Kassar, 2017).

Organizational commitment is defined as a psychological relationship between an organization and an individual (Yukongdi and Shrestha, 2020). Acosta et al., (2016) and Kmieciak et al., (2012) in Moussa and Arbi (2020) also showed that employee commitment contributes to the innovation capability. According to Meyer and Allen (1991) in Rahman et al., (2018), there are three concepts of commitments: normative commitment, affective commitment, and continuance commitment. Affective commitment points out to the emotional attachment of employee with their identification and involvement within 
Yohana Cahya Wibowo \& Natalia Christiani / The Effect of Affective Organizational Commitment towards Innovation Capability and Its Impact to Job Performance in Family Business / JEE, Vol. 9, No. 2, September 2020, pp 143-154

organization (Yiing and Ahmad, 2009). Normative commitment is a responsibility to continue working and stay loyal in organization (Moussa and Arbi, 2020). Continuity commitment refers to employee's commitment based on the costs that employee recognized whether they leave the organization (Yiing and Ahmad, 2009).

Affective commitment is considered as the most effective assessment of organizational commitment (Alniaçik et al., 2013). According to Nadeem (2010) and Yesil and Sozbilir (2013) in Moussa and Arbi (2020), many researches showed that role of commitment can improve individual motivation and performance. Oldham and Da Silva (2013), stated that an employee's creativity and their capability to innovate cannot surface unless they are committed to their work. In this term, they must set their commitment for both family and non-family members in order to execute their innovation ideas.

Innovation can happen if the company has an ability to innovate (Laforet, 2011). Referring to Eddelston et al., (2008) in Sreih and Kassar (2017), that both family and non-family members in Family Business must participate in making a process of innovation in order to develop their innovation capability. Lawson and Samson (2001) in Saunila and Ukko (2012), mentioned that innovation capability is the capability to transform ideas and knowledges continuously to become a new product, process and also new systems for the advantage for company and also stakeholders. Nowadays, developing innovation capability is important in order to prepare a company in the middle of challenging environments (Saunila and Ukko, 2012). Innovative capability influences to the job performance (Alasoini et al., 2007).

The job performance referred to the measurement of working behavior (Colquitt et al.,
2017 in Nangoy et al., 2020). According to Habeeb (2019), the concept of job performance is considered as the basic thing in orientations of human resource management and managerial management. Khan et al., (2010) in Younis and Sabra (2020), also designated job performance as the quality of employee's working behavior as a result of organizational commitment in order to fulfil the company's goals through finishing their tasks perfectly.

Shou et al., (2017) who investigated the relationship among innovation capability, relational resources, and the performance of thirdparty logistic (3PL) industry in China, found out that (1) innovation capability is related positively to job performance of 3PL company (2) innovation capability intervenes fully the correlation between firm performance and relational resources (3) innovation capability is the most important factor for relational resources to have an impact on firm performance. Another previous study done by Sungu et al., (2019) with the purpose to observe why and how organizational commitment affects the job performance. The research finds that there is a positive relationship between affective organizational commitment and job performance. This study also finds that normative organizational commitment positively affects job performance. Previous researches have not comprehensively examined the effect of affective organizational commitment towards innovation capability, and this background is the gap research for this study. Moussa and Arbi (2020) also examined the impact of human resource information system (HRIS) on individual innovation capability in human resource department (HR) of Tunisian companies. This research found out that (1) affective commitment of employee mediates the correlation between the usage of HRIS and 
Yohana Cahya Wibowo \& Natalia Christiani / The Effect of Affective Organizational Commitment towards Innovation Capability and Its Impact to Job Performance in Family Business / JEE, Vol. 9, No. 2, September 2020, pp 143-154

individual innovation capability (2) the more employees tied up with the company, the higher positive impact towards the HRIS. Rahman et al., (2018) also investigated the relationship between organizational commitment and organizational factors such as structure, culture, and top management in Bangladeshi service organization. The findings of this research are (1) decentralization influences affective and normative organizational commitment significantly and formalization do not influence significantly on affective organization and negatively influences normative commitment (2) top management support does not influence normative commitment significantly but positively influences affective commitment. Based on the previous explanation, the researcher intends to thoroughly investigate the affective organizational commitment and innovation capability affect the job performance in Family Business.

\section{METHOD}

This research type is using quantitative method and the sampling method used in this research is purposive sampling. Purposive sampling is a part of non-probability sampling. Purposive sampling uses sampling methods for selecting individuals based on the researcher's decision. These techniques include sampling of the highest variance, expert sampling and standard sampling of events (Berhnt, 2020).

Because the number of population is undefined, to determine the number of samples, the researcher intended to use calculation method from Hair et al., (2017). The minimum requirement needed for samples are five times the amount of the research indicators and the ratio that is used is $5: 1$. They also mentioned that the more samples collected, the more accu- rate the result will be. There are 20 indicators in this research, so the sampling size for this research is: $5 \times 20=100$ respondents. Data were analyzed using SEM-PLS.

\section{Research Design}

This research will be using the model of analysis as shown below:

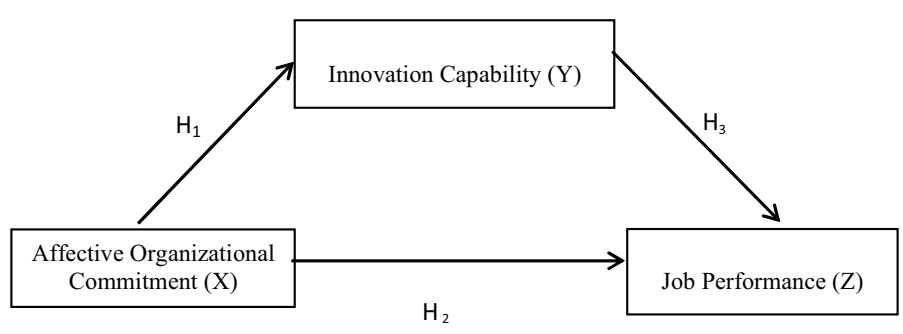

Figure 1 Model of Analysis

Source: Authors Processed Data, 2020

The targeted population for this research is the people of Family Business Community Universitas Ciputra Surabaya in the academic year of 2019-2 (even semester) and below is the characteristic of of family and non-family members:

\section{Table 1 Family and Non-Family Members} Characteristic

\begin{tabular}{cc}
\hline FAMILY MEMBERS & NON-FAMILY MEMBERS \\
\hline $\begin{array}{c}\text { Respondents are students of } \\
\text { Universitas Ciputra in }\end{array}$ & $\begin{array}{c}\text { Respondents are higher- } \\
\text { ranking officers in Family } \\
\text { Family Business Community } \\
\text { in 2019-2 who work at least } \\
\text { Businesses with a minimum } \\
\text { position of supervisor. }\end{array}$ \\
\hline Respondents contribute & Respondents are higher- \\
directly in managing Family & ranking officers in Family \\
Businesses with a minimum & Businesses with a minimum \\
of 6 months of employment. & 3 years of employment. \\
\hline
\end{tabular}

Source: Processed Data

\section{Measures}

The questionnaire is made in a form Likert Scale. The respondents get the questions and have to answer the situation on a metric scale. 
Yohana Cahya Wibowo \& Natalia Christiani / The Effect of Affective Organizational Commitment towards Innovation Capability and Its Impact to Job Performance in Family Business / JEE, Vol. 9, No. 2, September 2020, pp 143-154

The scale is from strongly disagree until strongly agree. A score 1 indicates the meaning of strongly disagree, meanwhile a score 5 indicates meaning of strongly agree. Affective Organizational Commitment $(\mathrm{X})$ is the independent variable, Innovation Capability $(\mathrm{Y})$ is intervening variable, while job performance $(\mathrm{Z})$ is the dependent variable. Below is the indicator of each variable:

\section{Descriptive Analysis}

The data of this research was gathered from 100 respondents who are the members and non-members of family businesses and filled the in the online questionnaires. The questionnaire consisted of 20 indicators statements from 1 independent variable, 1 dependent variable, and 1 intervening variable. All the data were

Table 2 Variables and Indicators

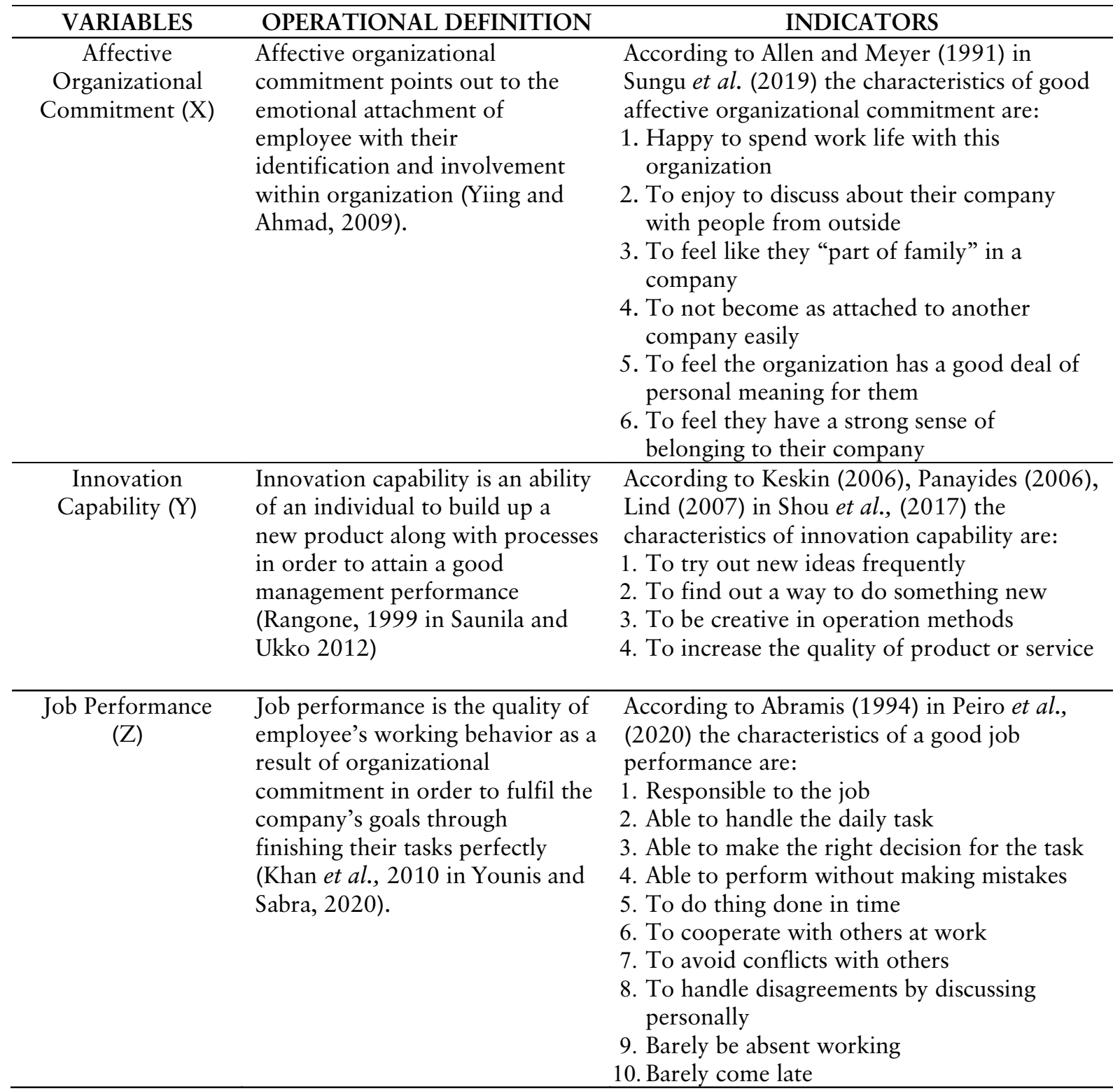

Source: Processed data 
Yohana Cahya Wibowo \& Natalia Christiani / The Effect of Affective Organizational Commitment towards Innovation Capability and Its Impact to Job Performance in Family Business / JEE, Vol. 9, No. 2, September 2020, pp 143-154

processed using SmartPLS 3.0 and the results were equal for both members $(50 \%)$ and nonmembers $(50 \%)$ and dominated by male respondents with $55 \%$, the dominating age range was 20 to 25 years old with $44 \%$ and dominated by product sector with $62 \%$ and mostly dominated by Commanditaire Vennotschap (CV) (55\%)

To evaluate convergent validity of reflective constructs, researchers consider the outer loadings of the indicators and the Average Variance Extracted (AVE). The data is consider valid if outer loading $>0.7$ and (AVE) $>0.5$ for each variable. Below is the result of outer loading:

Table 3 Outer Loading for Each Indicator

\begin{tabular}{cccc}
\hline Variable & Indicator & $\begin{array}{c}\text { Outer } \\
\text { Loading }\end{array}$ & Note \\
\hline Affective & X.2 & 0.795 & Valid \\
Organizational & X.3 & 0.751 & Valid \\
Commitment & X.4 & 0.765 & Valid \\
(X) & X.5 & 0.834 & Valid \\
& X.6 & 0.860 & Valid \\
\hline Innovation & Y.1 & 0.818 & Valid \\
Capability (Y) & Y.2 & 0.902 & Valid \\
& Y.3 & 0.882 & Valid \\
& Y.4 & 0.876 & Valid \\
\hline Job & Z.1 & 0.726 & Valid \\
Performance & Z.2 & 0.714 & Valid \\
(Z) & Z.3 & 0.761 & Valid \\
& Z.4 & 0.719 & Valid \\
& Z.5 & 0.777 & Valid \\
& Z.6 & 0.733 & Valid \\
\hline
\end{tabular}

Source: Processed Data

There are five indicators that are under the minimum outer loading value and it is considered invalid. Those five indicators are removed because it is under the minimum of outer loading value, 0.7 and the researcher did the second stage outer loading calculation, Based on the first stage of loading factor, there are still few of indicators that are not valid. To make the data valid, the lowest loading factor value should be taken out to make it valid. Those five indicators that are taken out from the table are $\mathrm{X} 1, \mathrm{Z7}, \mathrm{Z8}, \mathrm{Z9}$, and Z10. all indicators are valid with the minimum value 0.7 for each indicator.

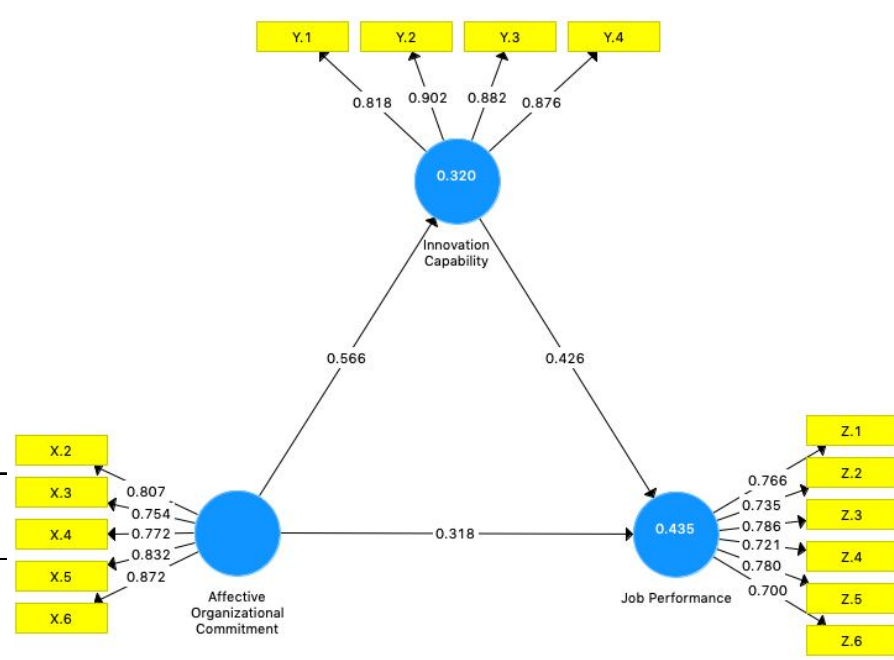

Figure 3 The Second Stage PLS Diagram Logarithm Source: Author's Processed Data, 2020

Table 4 AVE and Composite Reliability

\begin{tabular}{cccc}
\hline Variable & $\begin{array}{c}\text { Average } \\
\text { Variance } \\
\text { Extracted } \\
\text { (AVE) }\end{array}$ & $\begin{array}{c}\text { Composite } \\
\text { Reliability }\end{array}$ & Note \\
\hline $\begin{array}{c}\text { Affective } \\
\text { Organizational } \\
\text { Commitment } \\
\text { Innovation } \\
\text { Capability }\end{array}$ & 0.654 & 0.904 & Reliable \\
$\begin{array}{c}\text { Job } \\
\text { Performance }\end{array}$ & 0.560 & 0.884 & Reliable \\
\hline
\end{tabular}

Source: Processed Data

All variables are passed the value criteria $>0.5$ of Average Variance Extracted (AVE) value and valid with the minimum value 0.7 for each indicator for Composite Reliability test. 
Yohana Cahya Wibowo \& Natalia Christiani / The Effect of Affective Organizational Commitment towards Innovation

Capability and Its Impact to Job Performance in Family Business / JEE, Vol. 9, No. 2, September 2020, pp 143-154

\section{RESULT}

Table 5 Path Coefficients

\begin{tabular}{|c|c|c|c|c|c|c|}
\hline Relation & $\begin{array}{c}\text { Original } \\
\text { Sample }\end{array}$ & $\begin{array}{c}\text { Sample } \\
\text { Mean }\end{array}$ & $\begin{array}{c}\text { Standard } \\
\text { Deviation }\end{array}$ & $\begin{array}{c}\mathrm{T} \\
\text { Statistic }\end{array}$ & $\begin{array}{c}\mathrm{P} \\
\text { Values }\end{array}$ & Note \\
\hline $\begin{array}{l}\text { Affective } \\
\text { Organizational } \\
\text { Commitment } \\
\rightarrow \text { Innovation } \\
\text { Capability } \\
\end{array}$ & 0.566 & 0.572 & 0.071 & 7.936 & 0.000 & $\begin{array}{c}\text { H1 is } \\
\text { accepted }\end{array}$ \\
\hline $\begin{array}{l}\text { Affective } \\
\text { Organizational } \\
\text { Commitment } \\
\rightarrow \text { Job } \\
\text { Performance } \\
\end{array}$ & 0.426 & 0.425 & 0.098 & 4.326 & 0.000 & $\begin{array}{c}\mathrm{H} 2 \text { is } \\
\text { accepted }\end{array}$ \\
\hline $\begin{array}{l}\text { Innovation } \\
\text { Capability } \rightarrow \\
\text { Job } \\
\text { Performance }\end{array}$ & 0.318 & 0.332 & 0.095 & 3.331 & 0.001 & $\begin{array}{l}\mathrm{H} 3 \text { is } \\
\text { accepted }\end{array}$ \\
\hline
\end{tabular}

Source: Processed Data

Table 5 shows that all variables have reached the minimum T-statistic value, which is $\geq 1.96$, meaning that there is a significant effect among variables in this research, so that all hypotheses are acceptable in this research. It is shown on table 4.14 that affective organizational commitment towards innovation capability has T-statistic value 7.396 , which is more than the minimum value of T-statistic, 1.96. Thus, affective organizational commitment significantly affects innovation capability in Family Business and H1 is accepted. The second hypothesis, affective organizational commitment towards job performance has T-statistic value 4.230, which is more than the minimum value of T-statistic, 1.96. Thus, affective organiza-

Table 6 Cross-Validated Redundancy $\left(\mathrm{Q}^{2)}\right.$ and Coefficient of Determination $\left(\mathbf{R}^{2}\right)$

\begin{tabular}{ccc}
\hline Variable & $\mathbf{R}^{2}$ & $\mathbf{Q}^{2}$ \\
\hline Affective \\
Organizational \\
Commitment & & \\
\hline $\begin{array}{c}\text { Innovation } \\
\text { Capability }\end{array}$ & 0.320 & 0.237 \\
\hline Job Performance & 0.435 & 0.220 \\
\hline
\end{tabular}

Source: Processed Data tional commitment significantly affects job performance in Family Business and $\mathrm{H} 2$ is accepted. The third hypothesis, affective organizational commitment towards job performance has T-statistic value 3.317 , which is more than the minimum value of T-statistic, 1.96. Thus, innovation capability significantly affects job performance in Family Business and $\mathrm{H} 3$ is accepted.

Table 6 shows the result numbers of coefficient of determination $\left(\mathrm{R}^{2}\right)$ value. The dimension value of innovation capability is 0.320 and 0.435 for job performance and considered weak. It means that the dimension of innovation capability could be explained by $0.320(32 \%)$ of this variable and the rest will be explained by the other dimension outside this research, the dimension of job performance could be explained by $0.435(43.5 \%)$ of this variable and the rest will be explained by the other dimension outside this research.

As shown in Table 6 that affective organizational commitment has lack predictive relevance because the value is less than 0 meanwhile, the value of innovation capability and job performance are 0.237 and 0.220 respectively. It means that innovation capability and job performance have accurate predictive relevance to certain construct.

Table 7 Effect Sizes $\left(\mathrm{F}^{2}\right)$

\begin{tabular}{cccc}
\hline Variable & $\begin{array}{c}\text { Affective } \\
\text { Organizational } \\
\text { Commitment }\end{array}$ & $\begin{array}{c}\text { Innovation } \\
\text { Capability }\end{array}$ & $\begin{array}{c}\text { Job } \\
\text { Performance }\end{array}$ \\
\hline $\begin{array}{c}\text { Affective } \\
\text { Organizational } \\
\text { Commitment }\end{array}$ & - & 0.471 & 0.121 \\
\hline $\begin{array}{c}\text { Innovation } \\
\text { Capability }\end{array}$ & - & - & 0.218 \\
\hline Job & - & - & - \\
Performance & & & \\
\hline
\end{tabular}

Source: Processed Data 
Yohana Cahya Wibowo \& Natalia Christiani / The Effect of Affective Organizational Commitment towards Innovation Capability and Its Impact to Job Performance in Family Business / JEE, Vol. 9, No. 2, September 2020, pp 143-154

he value of affective organizational commitment towards innovation capability is 0.471 , meaning that it shows large effect sizes between variables meanwhile, the value of affective organizational commitment towards job performance is 0.121 , it means that there is a small effect between affective organizational commitment towards job performance. Lastly, the effect size value of innovation capability toward job performance is 0.218 , meaning that there are medium effect sizes between innovation capability towards job performance.

\section{DISCUSSION}

This research shows that there is a positive significant effect between affective organizational commitment to innovation capability in Family Business. Affective organizational commitment has T-statistic value 7.396 to innovation capability, which is more than the minimum value of T-statistic, 1.96 in path coefficients. It is supported by the previous research done by Moussa and Arbi (2020), many researches showed that role of commitment can improve individual motivation and performance. In this term, in order to execute their innovation ideas, they must set their commitment for both family and non-family members. This result also matches with previous study done by Oldham and Da Silva (2013) that employees creativity and their capability to innovate cannot surface unless they are committed to their work individually and in organization.

This research also shows that there is a positive significant effect between affective organizational commitment to job performance in Family Business. Affective organizational commitment has T-statistic value 4.230 to job performance, which is more than the minimum value of T-sta- tistic, 1.96 in path coefficients. This result matches with the previous study done by Devece et al., (2016), the more employees have a higher organizational commitment, the more efforts showed in job performance. It also supported with the previous study from Moussa and Arbi (2020), the more staff develop their emotional affinity, the more they feel like they are part of a company that needs to achieve every goal given by the company.

This research shows that there is a positive significant effect between innovation capability to job performance in Family Business. Innovation capability has T-statistic value 3.317 to job performance, which is more than the minimum value of T-statistic, 1.96 in path coefficients. This result matches with the previous study done by in Saunila et al., (2014) that innovation capability and job performance are connected to each other. It is supported by previous research done by Bisbe and Otley (2004) that there is a positive relationship between innovation and performance. it means that innovation capability significantly affects the job performance.

\section{REFERENCES}

Alasoini, T., Heikkila“, A., Ramstad, E. and Ylo“stalo, P. (2007), Enquiry as New Way of Gathering Information in Tykes-Program: Preliminary Results, Finish Ministry of Labour, Helsinki, pp. 55-71, In Workpolitical Journal 2/2007 (in Finnish).

Al-Homayan, A. M., Shamsudin, F. M., Subramaniam, C. and Islam, R. (2013), "Effects of Job Stress and Organizational Support on the Relationship between Job Demand Resources and Nurses' Job Performance in Saudi Public Hospitals", Australian Jour- 
Yohana Cahya Wibowo \& Natalia Christiani / The Effect of Affective Organizational Commitment towards Innovation Capability and Its Impact to Job Performance in Family Business / JEE, Vol. 9, No. 2, September 2020, pp 143-154

nal of Basic and Applied Sciences, Vol. 7 No. 10, pp. 7-19

Alniaçik, E., Alniaçik, Ü., Erat, S. \& Akçin, K., (2013). Does Person-Organization Fit Moderate the Effects of Affective Commitment and Job Satisfaction on Turnover Intentions? Procedia-Social and Behavioral Sciences, Volume 99, pp. 274-281.

Berndt, A. E. (2020). Sampling Methods. Journal of Human Lactation, 36(2), 224-226.

Bisbe, J. \& Otley, D. (2004). The Effects of the Interactive Use of Management Control Systems on Product Innovation. Accounting, Organizations and Society, 29(8), 709737.

Brunetto, Y. and Farr-Wharton, R. (2003). "The Commitment and Satisfaction of LowerRanked Police Officers: Lessons for Management", Policing: An International Journal of Police Strategies \& Management, Vol. 26 No. 1, pp. 43-63.

Chen, J. C., Silverthorne, C., \& Hung, J. Y. (2006). Organization Communication, Job Stress, Organizational Commitment, and Job Performance of Accounting Professionals in Taiwan and America. Leadership \& organization Development journal.

Coelho, F., Augusto, M., \& Lages, L. (2011). Contextual Factors and the Creativity of Frontline Employees: The Mediating Effects of Role Stress and Intrinsic Motivation on Economy and Finance Organization in Tehran. Journal of Retailing, 87.

Colquittt, J. A., LePine, J. A., \& Wesson, M. J. (2017). Organizational Behavior: Improving Performance and Commitment in the Work Place. 5th ed. New York: McGrawHill Education.

Cooper, D. \& Schindler, P. (2014). Business Research Methods. New York: McGraw-Hill.
Damanpour, F. (1991). "Organizational Innovation: A Meta-Analysis of Effects of Determinants and Moderators". Academy of Management Journal, Vol. 34, No. 3, pp. 555-590.

Devece, C., Palacios-Marqués, D., \& Alguacil, M. P. (2016). Organizational Commitment and Its Effects on Organizational Citizenship Behavior in a High-Unemployment Environment. Journal of Business Research, 69(5), 1857-1861.

Etikan, I., Musa, S. A., \& Alkassim, R. S. (2016). Comparison of Convenience Sampling and Purposive Sampling. American Journal of Theoretical and Applied Statistics, 5(1), 1-4.

Fahed-Sreih, J. \& El-Kassar, A. N. (2017). Strategic Planning, Performance, and Innovative Capabilities of Non-Family Members in Family Businesses. International Journal of Innovation Management, 21(07), 1750052.

Forker, L. B., Vickery, S. K., \& Droge, C. L. (1996). The Contribution of Quality to Business Performance. International Journal of Operations \& Production Management.

Garson, G. D. (2016). Partial Least Squares: Regression and Structural Equation Models. Asheboro, NC: Statistical Associates Publishers.

Grant, R. (2017). Recordkeeping and Research Data Management: a Review of Perspectives. Records Management Journal.

Habeeb, S. (2019), "Relation between Organisational Citizenship Behavior, Workplace Spirituality and Job Performance in BFSI sector in India”. Problems and Perspectives in Management, Vol. 17, No. 1, pp. 176-188.20. 
Yohana Cahya Wibowo \& Natalia Christiani / The Effect of Affective Organizational Commitment towards Innovation Capability and Its Impact to Job Performance in Family Business / JEE, Vol. 9, No. 2, September 2020, pp 143-154

Hackett, R.D., Lapierre, L.M., and Hausdorf, P.A. (2001). "Understanding the Links between Work Commitment Constructs". Journal of Vocational Behaviours, Vol. 58, pp. 392-413.

Hair, J. F., Black, W. C., Babin, B. J., \& Anderson, R. E. (2014). Multivariate Data Analysis: Pearson New International Edition. Essex: Pearson Education Limited.

Hair Jr, J. F., Hult, G. T. M., Ringle, C., \& Sarstedt, M. (2016). A Primer on Partial Least Squares Structural Equation Modelling (PLS-SEM). Sage Publications.

Haldma, T., Näsi, S., Grossi, G., Saunila, M., \& Ukko, J. (2012). A Conceptual Framework for the Measurement of Innovation Capability and Its Effects. Baltic Journal of Management.

Hassan, B., Saleh, K. M., Awang, H., \& Alias, M. (2017). "Students' Perceptions of Their Teachers' Performance in Teaching Engineering Drawing in Nigerian Tertiary Institutions". Path of Science, Vol. 3, No. 10, pp. 3001-3012.

Heale, Roberta \& Twycross, Alison. (2015). Validity and Reliability in Quantitative Research. Evidence-Based Nursing. 18. 6667.

Horton, T. P. (1986). Managing in a Family Way. Management Review, 75(2), 3.

Hult, G. T. M., Hurley, R. F., \& Knight, G. A. (2004). Innovativeness: Its Antecedents and Impact on Business Performance. Industrial Marketing Management, 33(5), 429-438.

Joshi, A., Kale, S., Chandel, S., \& Pal, D. (2015). Likert Scale: Explored and Explained. British Journal of Applied Science \& Technology, 7(4), 396-403.
Kellermanns, F. W., Eddleston, K. A., Barnett, T., \& Pearson, A. (2008). An Exploratory Study of Family Member Characteristics and Involvement: Effects on Entrepreneurial Behavior in the Family Firm. Family Business Review, 21(1), 114.

Khan, '. ñI\%, Ziauddin, Z., Jam, F. A., and Ramay, M. I. (2010). “The Impacts of Organizational Commitment on Employee Job Performance"., European Journal of Social Sciences, Vol. 15, pp. 292-298.

Khan, T. I. (2011). Job Involvement as Predictor of Employee Commitment: Evidence from Pakistan. International Journal of Business and Management, 6(4).

Kmieciak, R., Michna, A., \& Meczynska, A. (2012). Innovativeness, Empowerment, and IT Capability: Evidence from SMEs. Industrial Management \& Data Systems, 112(5), 707-728.

Koopmans, L., Bernaards, C., Hildebrandt, V., van Buuren, S., van der Beek, A. J., \& de Vet, H. C. W. (2012). "Development of an Individual Work Performance Questionnaire", International Journal of Productivity and Performance Management, Vol. 62 No. 1, pp. 6-28.

Laforet, S. (2011), "A Framework of Organisational Innovation and Outcomes in SMEs". International Journal of Entrepreneurial Behaviour \& Research, Vol. 17, No. 4, pp. 380-408.

Lawson, B. \& Samson, D. (2001). Developing Innovation Capability in Organisations: A Dynamic Capabilities Approach. International Journal of Innovation Management, 5(03), 377-400.

Lind, D., Marchal, W., \& Wathen, S. (2017). Two-Sample Tests about Proportions. Sta- 
Yohana Cahya Wibowo \& Natalia Christiani / The Effect of Affective Organizational Commitment towards Innovation Capability and Its Impact to Job Performance in Family Business / JEE, Vol. 9, No. 2, September 2020, pp 143-154

tistical Techniques in Business \& Economics, 17th ed., pp. 550ff. McGraw-Hill.

Meyer, J. P. \& Herscovitch, L. (2001). Commitment in the Workplace: Toward a General Model. Human Resources Management Review, 11, 299-326.

Meyer, J. P. and Allen, N. J. (1991). "A ThreeComponent Conceptualization of Organizational Commitment". Human Resource Management Review, Vol. 1, No. 1, pp. 61-89.

Moussa, N. B. \& El Arbi, R. (2020). The Impact of Human Resources Information Systems on Individual Innovation Capability in Tunisian Companies: The Moderating Role of Affective Commitment. European Research on Management and Business Economics.

Mowday, R. T., Steers, R. M., \& Porter, L. W. (1979). The Measurement of Organizational Commitment. Journal of Vocational Behavior, 14(2), 224-247.

Nadeem, M. (2010). Role of Training in Determining the Employee Corporate Behavior with Respect to Organizational Productivity: Developing and Proposing a Conceptual Model. International Journal of Business and Management, 5(12).

Nangoy, R., Mursitama, T., Setiadi, N., \& Pradipto, Y. (2020). Creating Sustainable Performance in the Fourth Industrial Revolution Era: The Effect of Employee's Work Well-Being on Job Performance. Management Science Letters, 10(5), 1037-1042.

Oldham, G. \& Da Silva, N. (2013). The Impact of Digital Technology on the Generation and Implementation of Creative Ideas in the Workplace. Computers in Human Behavior, 42, 5-11, in Press.
Olsson, A., Wadell, C., Odenrick, P., \& Bergendahl, M. N. (2010). "An Action Learning Method for Increased Innovation Capability in Organizations". Action Learning: Research \& Practice, Vol. 7, No. 2, pp. 167-179.

Rahman, S., Islam, M. Z., Abdullah, A. D. A., \& Sumardi, W. A. (2018). Empirical Investigation of the Relationship between Organizational Factors and Organizational Commitment in Service Organizations. Journal of Strategy and Management.

Rangone, A. (1999). A Resource-Based Approach to Strategy Analysis in Small-Medium Sized Enterprises. Small Business Economics, 12(3), 233-248.

Roberts, P. W. \& Amit, R. (2003). The Dynamics of Innovative Activity and Competitive Advantage: The Case of Australian Retail Banking, 1981 to 1995. Organization Science, 14(2), 107-122.

Sabra, R. Y. H. (2020). Impact of Job Characteristics on Job Performance in Greater Amman Municipality. Global Journal of Management and Business Research.

Saunders, M., Lewis, P., \& Thornhill, A. (2016). Seventh Edition: Research Methods for Business Students. Harlow: Pearson Education Limited.

Salehi, M., Mohammadpour, A., Mohammadi, M., \& Aminghafari, M. (2018). A Modified F-test for Hypothesis Testing in LargeScale Data. Journal of Biopharmaceutical Statistics, 28(6), 1078-1089.

Saunila, M. \& Ukko, J. (2013). Facilitating Innovation Capability through Performance Measurement. Management Research Review.

Sheldon, M. E. (1971). Investments and Involvements as Mechanisms Producing Com- 
Yohana Cahya Wibowo \& Natalia Christiani / The Effect of Affective Organizational Commitment towards Innovation Capability and Its Impact to Job Performance in Family Business / JEE, Vol. 9, No. 2, September 2020, pp 143-154

mitment to the Organization. Administrative Science Quarterly, 16(2), 143-150.

Shou, Y., Shao, J., \& Chen, A. (2017). Relational Resources and Performance of Chinese Third-Party Logistics Providers. International Journal of Physical Distribution \& Logistics Management.

Silva, M. J. M., Simo es, J., Moreira, J., \& Sousa, G. (2012). "Investment and Expenditure on Innovation Activities and Innovative Capability: Empirical Evidence from Portuguese Services Firms and KIBS”. International Business Research, Vol. 5, No. 2, pp. 114-122.

Soto-Acosta, P., Popa, S., \& Palacios-Marqués, D. (2016). Social Web Knowledge Sharing and Innovation Performance in Knowledge-Intensive Manufacturing SMEs. The Journal of Technology Transfer, 40(4), 581601.

Sungu, L. J., Weng, Q., Hu, E., Kitule, J. A., \& Fang, Q. (2020). How Does Organizational Commitment Relate to Job Performance? A Conservation of Resource Perspective. Human Performance, 33(1), 52-69.

Tuominen, M. and Hyvo"nen, S. (2004). "Organisational Innovation Capability: a Driver for Competitive Superiority in Marketing Channels”. The International Review of Retail, Distribution, and Consumer Research, Vol. 14, No. 3, pp. 277293.
Yesil, S. \& Sozbilir, F. (2013). An Empirical Investigation into the Impact of Personality on Individual Innovation Behaviour in the Workplace. Procedia - Social and Behavioral Sciences, 81.

Yiing, L. H. \& Ahmad, K. Z. B. (2009). The Moderating Effects of Organizational Culture on the Relationships between Leadership Behaviour and Organizational Commitment and between Organizational Commitment and Job Satisfaction and Performance. Leadership \& Organization Development Journal.

Yliherva, J. (2004). "Management Model of an Organisation's Innovation Capabilities Development of Innovation Capabilities as Part of the Management System". Dissertation, Department of Industrial Engineering and Management, University of Oulu, Oulu (in Finnish).

Yousef, D. A. (2000). Organizational Commitment and Job Satisfaction as Predictors of Attitudes toward Organizational Change in a Non-Western Setting. Personnel Review, 29(5), 567-592. doi:10.1108/ 00483480010296401.

Yukongdi, V. \& Shrestha, P. (2020). The Influence of Affective Commitment, Job Satisfaction, and Job Stress on Turnover Intention: A Study of Nepalese Bank Employees. Review of Integrative Business and Economics Research, 9, 88-98. 
Yohana Cahya Wibowo \& Natalia Christiani / The Effect of Affective Organizational Commitment towards Innovation Capability and Its Impact to Job Performance in Family Business / JEE, Vol. 9, No. 2, September 2020, pp 143-154 